\title{
A FEW REMARKS ABOUT P. MULLER'S METHOD OF PELVIMETRY.
}

By RENÉ P. KOENIG, M.D. (Berne), M.R.C.S., L.R.C.P., Chef de Clinique and Privat-Docent of Gynocology in the University of Geneva (Switzerland).

IN the April issue of the Journal of Obstetrics and Gyncecology of the British Empire there appeared a paper by Dr. Munro Kerr giving an account of a new method for estimating the relative sizes of the foetal head and maternal pelvis. Speaking first of "Müller's method," Dr. Kerr gives Müller (and Pinard) the credit for having been the first to describe a method for testing these relative sizes. Müller's method, to the usefulness of which he testifies, he has frequently, both during labour and pregnancy, employed for the purpose of estimating the proportions of the head and pelvis; but he has often failed to obtain by it a sufficiently accurate estimate, one great disadvantage being that an assistant has to grasp the head and press it down into the pelvis. Pinard's method (estimation by purely external manipulation) having the advantage over Müller's that all manipulations are performed by the operator himself, Dr. Kerr advocates a combination of the two methods, which he calls a new one. Now I am very much pleased to see an appreciation of Müller's method by so eminent a gynæcologist as Dr. Munro Kerr. Having been for two years first assistant at P. Müller's clinique I have had ample opportunity of testing the value of his method, and I always deplored the fact that it is so little known, and still less practised, though it may be quoted incidentally in the text-books, English as well as Continental.

But Dr. Kerr's reservations call for some remarks. His description of Müller's method is not quite correct, and his own "combined method" has been in use at the Berne Gynæcological Clinique for many years, as well as at the Geneva Clinique since Dr. Jentzer's appointment as Professor of Gynæcology. In his original paper on the subject ${ }^{1}$ Müller first describes the manipulations which, much later, Pinard took up again, and which are referred to by Dr. Kerr as Pinard's method. 'Then he goes on to say : "Should this pressure by external manipulations not succed rapidly it is necessary that one hand should leave the abdomen and its index finger be introduced into the vagina, whilst the pressure is continued with the other hand." The examination from the vagina is needed to verify the actual descent of the head, which may be simulated by 
only the anterior part of the head following the pressure, the whole head rotating around the occipito-frontal diameter. In fact, ever since its origin the method has been practised in the manner advocated by Dr. Kerr. But very often the external hand, bent as it is at the wrist, is not powerful enough to press down the foetal head. It may be that a British grip is more efficient than our own! Anyway, we often noticed that in cases where Müller's pelvimetry was specially called for our own hand was not sufficient, and we therefore needed an assistant to apply this pressure. The assistant's part was always considered to be only an incidental help to the external hand, when the abdominal muscles, the uterus, or the brim of the pelvis itself offered too great a resistance to be overcome by one hand alone.

Further, I always heard P. Müller himself teach his method as being not only intended to help in deciding the most suitable time for the inducement of premature labour, but chiefly and primarily as the really best method of pelvimetry. He used to insist on the small value of the ordinary pelvimetry with callipers alone, as the chief point is not the contraction of the pelvis (which, by the way, can only be very roughly measured by callipers), but the relation between the fœtal head and the maternal pelvis. This he illustrated by pointing to the great number of contracted pelves (comparatively frequent at Berne) opposing no real obstacle to the passage of the head, the latter being often small and soft in such cases. Lastly, Müller lays great stress on the estimation of what proportion of the surface of the head lies beyond the brim, or remains beyond it after the pressing in (impression as he calls it). All this is clearly set forth by Müller in the paper referred to above, and by Beuttner, ${ }^{2}$ one of Müller's former assistants.

As will be seen, Kerr's method is identical with the one introduced by Peter Müller in 1885, and in use ever since at the Berne clinique, and I trust that Dr. Kerr's authority will contribute to its being appreciated as it really deserves, whether it be known as Kerr's or Müller's method, although I cannot help thinking that it would be only fair to call it after the latter's name.

\section{REFERENCES.}

1 Müller (Peter). "Ueber das Einpressen des Kopfes in den Beckenkanal zu diagnostischen Zweeken." Sammlung klinischer Vorträge von Richard Volkmann, 1885, No. 264.

2 Beutriner (Oscar). "Zur Frage der künstlichen Frühgeburt bei Beckenenge." Archiv. für Gynctologie, 1895. Bd. 48, p. 269. 